\title{
Social Media Trends among Pakistani University Students
}

\author{
Hamid Ikram ${ }^{1}$, Tayyaba M Akram², Aisha Manzoor ${ }^{2}$, Fatima Aziz ${ }^{2}$ \\ ${ }^{l}$ GC University Faisalabad, ${ }^{2}$ University of the Punjab
}

\begin{abstract}
In this 21 st century, social networking sites have evolved rapidly and universally. In Pakistan, there were times when social media were considered a deed of redundant and lazy youth. But now, social media is becoming a little more than just a sharing and communication tool; it is very influential in fact. This present quantitative inquiry aimed to uncover the popularity of different social networking sites among Pakistani university students. Also, this study explored the role of social media in students, academics. This study included 956 university students (371 male, 584 female), and recorded their perceptions through a questionnaire - developed by the researchers. The data were analysed by using $t$ test, Correlation, and ANOVA tests. The findings revealed the trends of social media and reasons for students using social media. The students revealed their use of social websites was not only entertainment, but also communication with classmates and teachers. The students were not sure whether social networking sites helped in improving their grades, however, their grades were neither negatively affected by the use of social networking sites.
\end{abstract}

\section{Introduction}

Since, the inception of social media technologies the trends of its use are diverse. Although, social media is playing significant role in the field of education, however, studies have uncovered that most users use social media platform such as Facebook just to connect with their old friends, make new ones, and spend their leisure time. As the social media developed, only computer literate people started networking as a hobby, but now things are way different. In general, it is perceived a status symbol to sign up for social networking sites [2]. With the advancement in technology, especially the smartphones, the use of social media has also been tremendously increased. The popular social media platforms among users are Facebook, Twitter, LinkedIn, Instagram, and WhatsApp [3]. Social networking has a multitude of implications in the field of education. In addition, some studies proved the demographics variables are not barriers for using social media.

Mostly, the digital technology has impacted learners' skills and abilities in many aspects of their education [4]. The intense use of Internet could affect students' educational performance both positively or adversely. However, Kirschner \& Karpinski did not find any significant effect of computer technology on learner's academic performance [5]. Moreover, there was no correlation found between the duration of Internet use and students' grades [6]. In general, social media provides an opportunity to learners to participate in online learning groups by using technological tools available to them [7]. The incorporation of social media in everyday pedagogy could increase the quality of instruction and retention of students' learning [8]. Forkosh-Baruch and Hershkovitz concluded that twitter can improve the grades of students and can be helpful in their academic career in different ways [9]. Shah et al. found that the time spent on Internet affects its users and the impact is determined by the nature of its use [10]. Sometimes, students use Internet to consume relevant information than using the Internet for recreation. Moreover, there are research findings proving the positive effect of social media on learning; as few inquiries uncovered that both learners and teachers feel socializing on Facebook with each other is quite appropriate and justified [11]. The learners also held the view that social media let them share information in formal educational settings. Beside active social media platforms, Churchill found that blogging in education create a good learning environment [12]. Roblyer has found that some researchers have swiftly comprehended that social media should be integrated into the scholastic institutions, so that it can improve student teacher communication [13]. The social learning theories propose that the advances in human behaviour are made through communication, interaction, and observations in a social context [14].

In their study, Keenan and Shirii looked how could social media promote sociability through the use of different social media platforms [15]. Their inquiry found that many platforms could be utilized to promote friendliness between Internet users. Another study, conducted by Mazer found Facebook as the 
most common social media network for both teachers and students [16]. However, Haq and Chand discovered the harms of using Facebook for students' academic grades and found this adverse effect was more common among male students. On the other hand, Facbook was most common tool to use for connecting with existing friends [17]. Pempek et al., exposed the students do not use Facebook for more than 30 minutes every day [18]. The study conducted by Kirschner and Karpinski explored the adverse effect of social media on students' performance [19]. The above stated findings were consistent with the findings of Boogart, Canales et al., and Junco [20] [21] [22].

Generally, the students' responses leaned towards using online networking for their academics and participating in focussed group discussion related to their education. According to Ahmed and Qazi, the social media platforms does not have negative effects on students learning as students could manage their time appropriately to take out sometime for social media without harming their studies [23]. A research conducted by Curran and Lenon concluded that using social media does not harmfully affect students' academic performance. Curran and Lenon reported that $11 \%$ students used social media websites for education and $45 \%$ learners described their social media use for specific courses such as the English language [24]. The social media earned more popularity and being extensively used among students from second half of the last decade [25]. Furthermore, Kirschner and Karpinski claimed that students like to browse irrelevant websites while doing their studwork on the Internet. This would impact their learning process and devotion to the studies. Kirschner \& Karpinski found that participants' ability to multitask and getting information simultaneously from different sources lead to confusion, waste of time, and increased chances of mistakes. On the other hand, those participants who rely on one source at a time have more quality information in less time. In simple words, those people who chose not to consume information from many sources have higher success rate in less time. Digital social networking has changed our culture of communication since the inventions of multiple online networking platforms including Facebook. According to Youth, Facebook is a big tool for students to waste their study time by getting into Facebook's various recommended pages, groups, and profiles. The empirical findings from Rosen, Carrier, and Cheever reported that learners of all levels who checked Facebook for one time in 15 minutes duration achieved lower grades [1].

\section{Research Methodology}

The following three research questions were answered in this present inquiry.
1. Which is a most common social media platform for students?

2. How social media affect university students' academic achievement?

3. How the use of social media differs among participants based on their demographics?

\subsection{Sample of the study}

The three major universities of Punjab province i.e. University of the Punjab, University of Lahore, and University of Sargodha were part of this study's target population. The selected sample contained 956 students (371 male, 584 female). The samples were collected through stratified convenience sampling from the above-mentioned three major universities of Punjab province of Pakistan.

\subsection{Research instrument}

The nature of this study was descriptive, and the data was collected with a researcher's developed, validated, and reliable questionnaire. The items of the research instrument intended to collect the perceptions of university students about their use of social media. This questionnaire was made on a fivepoint Likert scale and consisted 35 items plus the demographics' questions.

\section{Data Analysis and Findings}

The mean, standard deviation, percentage, correlation, t-test, and one-way ANOVA were used for the purpose of data analysis in this paper.

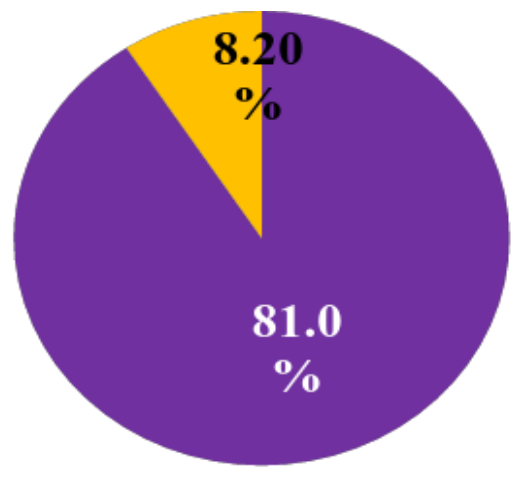

Figure 1. Social media use

The above figure illustrates the comparison of social media use among university students. Figure 1 shows that $81 \%$ study participants used social networking sites and $8.2 \%$ were not using any kind of social media platform, whereas rest of the participants did not answer this question. 
Table 1. Comparing the common social media platform

\begin{tabular}{lll}
\hline Sr.\# & Platform & Users \\
\hline 1 & Facebook & $85 \%$ \\
2 & LinkedIn & $2 \%$ \\
3 & Twitter & $19 \%$ \\
4 & YouTube & $20 \%$ \\
5 & MySpace & $10 \%$ \\
6 & Flickr & $10 \%$ \\
\hline
\end{tabular}

Table 1 shows that most of the participants used Facebook (85\%), while the use of YouTube, Twitter, MySpace, Flickr were (20\%, 19\%, 10\%, 10\%) respectively. To answer this question, the participants were allowed to choose more than one social media platform.

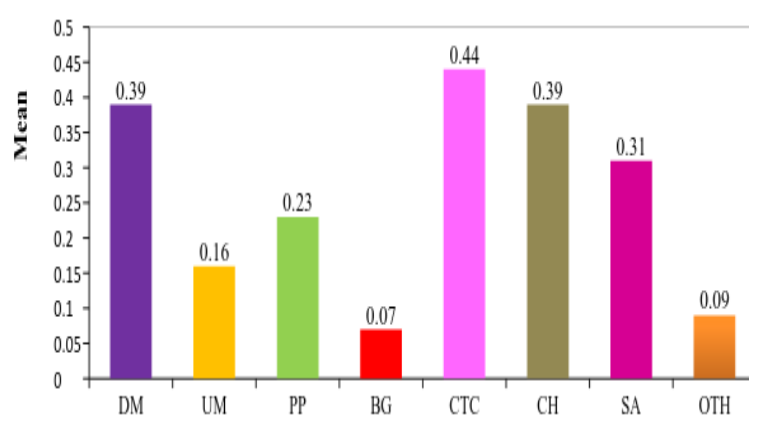

Figure 2. Purpose of using social media

Figure 2 shows the findings related to the purpose of using social media for students. Generally, it is assumed that social media is only used for entertainment but the data from the university students showed that most of the participants used social media for communication with their classmates and teachers as well.

Table 2. Percentage of students on social media improves grades

\begin{tabular}{rrrrc}
\hline SA & A & UN & DA & SDA \\
10.2 & 24.3 & 15.6 & 24.2 & 8.7 \\
\hline
\end{tabular}

Table 3. Percentage of students on the effect of social media on grades

\begin{tabular}{ccccc}
\hline SA & A & UN & DA & SDA \\
\hline 14.2 & 27.9 & 13.5 & 18.6 & 8.7 \\
\hline
\end{tabular}

Table 2 reveals that totally $34.5 \%$ students agreed that social networking improved their grades but $32.9 \%$ disagreed. On the other hand, $15.6 \%$ were not sure if social media has any role in their grades.
Conversely, according to Table 3, 42.1\% students explicitly said that social networking affected their grades.

Table 4. Social media use and negative attitudes of students

\begin{tabular}{lccc}
\hline Variable & $\mathbf{N}$ & $\boldsymbol{r}$ & $\boldsymbol{p}$ \\
\hline $\begin{array}{l}\text { Negative attitude and use of } \\
\text { social media }\end{array}$ & 908 & 0.31 & 0.00 \\
\hline
\end{tabular}

Table 4 confirms the statistically significant correlation between the use of social networking sites and the negative attitude of students towards social media. However, the relationship between two variables is positively moderate. According to students' perceptions, social media negatively slightly affected their studies.

Table 5. Social media use by gender

\begin{tabular}{lccccc}
\hline Gender & $\boldsymbol{N}$ & $\boldsymbol{M}$ & $\boldsymbol{d f}$ & $\boldsymbol{t}$-test & $\boldsymbol{p}$ \\
\hline Female & 541 & 96.67 & 906 & 0.36 & 0.71 \\
Male & 367 & 96.20 & & & \\
\hline
\end{tabular}

Table 6. Social media effect by gender

\begin{tabular}{lccccc}
\hline Gender & $\boldsymbol{N}$ & $\boldsymbol{M}$ & $\boldsymbol{d f}$ & $\boldsymbol{t}$-test & $\boldsymbol{p}$ \\
\hline Female & 541 & 16.14 & 905 & 0.50 & 0.61 \\
Male & 367 & 16.00 & & & \\
\hline
\end{tabular}

Table 5 and 6 shows the students of both genders held the similar views about the social media role in their studies as the $t(0.36,0.50)$ values were not statistically significant $(\mathrm{p}>0.05)$.

Table 7. Comparison of semester scores of students and the use of social media

\begin{tabular}{|c|c|c|c|c|c|}
\hline Semester & $N$ & $M$ & $d f$ & $F$ & $p$ \\
\hline $1^{\text {st }}$ & 21 & 99.33 & 11 & 0.61 & $\begin{array}{c}0.8 \\
1\end{array}$ \\
\hline $2^{\text {nd }}$ & $\begin{array}{c}32 \\
4\end{array}$ & 95.06 & & & \\
\hline $3^{\text {rd }}$ & 59 & 98.47 & & & \\
\hline $4^{\text {th }}$ & $\begin{array}{c}33 \\
0\end{array}$ & 97.70 & & & \\
\hline $5^{\text {th }}$ & 7 & 92.71 & & & \\
\hline $6^{\text {th }}$ & 98 & 94.62 & & & \\
\hline $7^{\text {th }}$ & 6 & 93.66 & & & \\
\hline $8^{\text {th }}$ & 19 & 95.68 & & & \\
\hline
\end{tabular}

Table 7 reveals that there was no statistically significant effect of students' semester scores on their use of social media. 
Table 8. Effect of social media on students' academics in different faculties

\begin{tabular}{|c|c|c|c|c|c|}
\hline Faculty & $N$ & $M$ & $d f$ & $F$ & $p$ \\
\hline Education & 11 & & 1 & 1.4 & 0.1 \\
\hline & 8 & 99.43 & 2 & 3 & 4 \\
\hline Commerce & 12 & 96.38 & & & \\
\hline & 6 & 90.38 & & & \\
\hline Life sciences & 11 & 92.34 & & & \\
\hline Sciences & 12 & & & & \\
\hline & 0 & 96.54 & & & \\
\hline Social sciences & 72 & 93.59 & & & \\
\hline Economics \& & & & & & \\
\hline $\begin{array}{l}\text { management } \\
\text { sciences }\end{array}$ & 65 & 97.69 & & & \\
\hline $\begin{array}{l}\text { Health } \\
\text { sciences }\end{array}$ & 78 & 99.65 & & & \\
\hline $\begin{array}{l}\text { Management } \\
\text { sciences }\end{array}$ & 11 & 93.54 & & & \\
\hline $\begin{array}{l}\text { Information } \\
\text { technology }\end{array}$ & 23 & 93.95 & & & \\
\hline Allied sciences & 19 & $\begin{array}{c}100.6 \\
8\end{array}$ & & & \\
\hline $\begin{array}{l}\text { Management } \\
\text { \&administrativ }\end{array}$ & & & & & \\
\hline e sciences & 70 & 95.04 & & & \\
\hline $\begin{array}{l}\text { Sargodha } \\
\text { University }\end{array}$ & & & & & \\
\hline $\begin{array}{l}\text { Arts Sargodha } \\
\text { University } \\
\text { Science }\end{array}$ & 30 & 93.30 & & & \\
\hline $\begin{array}{l}\text { Sargodha } \\
\text { University }\end{array}$ & 66 & 99.53 & & & \\
\hline
\end{tabular}

According to table 8, students related to education major were using more social media as compared to other fields. However, the different faculties of three universities were statistically significantly different on using social networking sites as the $\mathrm{p}>0.05$.

\section{Conclusion}

This present study uncovered the students' awareness about the possible uses of social networking platforms; however, the true benefits of such networking tools for the teaching and learning process remained unknown. This study found that a majority of university level students do social networking and among them Facebook was the most common tool for networking among students. Though, twitter and YouTube remained their second favourites. According to students' responses, the purpose of using social media was not entirely entertainment but also educational. The students' purpose of social networking was also to communicate with teachers and classmates for chatting and downloading music.
They also responded that they have desire to share knowledge and learn from others through social media. The participants were not sure about whether social media impacted their grades. Also, the views of male and female respondents were not different about the role of social networking sites. The different demographic factors did not impact students' social networking. The students did social networking in daily routine and that use did not affect their dailybased educational work. They could maintain a good balance between social networking and their studies.

\section{Implications and Recommendations}

The faculty members could engage their students through social media by creating the classroom discussion groups, which are available to launch at the social networking sites. This could take student away from using social media for non-academic purposes. An extensive research can be done to explore the effect of social networking on higher education. An extensive research could also be done to find out to which degree students can negotiate between academic uses of social media. A future research can be done to see whether the extensive use of social media affects the student's confidence level.

\section{References}

[1] Rosen, L. D., Carrier, L. M., \& Cheever, N. A. (2013) "Facebook and texting made me do it: Media-induced taskswitching while studying", Computers in Human Behavior 29 (3), pp. 948-958.

[2] Boyd, D. M., \& Ellison, N. B. (2007) "Social Network Sites: Definition, History, and Scholarship", Journal of Computer-Mediated Communication 13 (1), pp. 210-230.

[3] Coyal, C., \& Vaughn, H. (2008) "Social Networking: Communication Revolution Evolution", Bell Labs Technical Journal 13 (2), pp. 13-18.

[4] McCarthy, J. (2010) "Blended Learning Environments: Using Social Networking Sites to Enhance the First Year Experience", Australasian Journal of Educational Technology 26 (6), pp. 729-740.

[5] Kirschner, P. A., \& Karpinski, A. C. (2010) "Facebook and Academic Performance", Computers in Human Behaviour 26, pp. 1237-1245.

[6] Hunley. S. A., Evans. J. H., Delogado-Hachey, M., Krise, J., Rich., \& Schell, C. (2005) "Adolescent Computer Use and Academic Achievement", Adolescence 40 (158), pp. 307-318.

[7] Forkosh-baruch, A., \& Hershkovitz, A. (2012) "A Case Study of Israeli Higher Education Institutes Sharing Scholarly Information with the Community via Social Networks", Internet and Higher Education, 15 (1), pp. 5868. 
[8] Shah, D. V., Kwak, N., \& Holbert, R. L. (2001) "Connecting and Disconnecting with Civic Life: Patterns of Internet Use and the Production of Social Capital", Political Communication 18 (2), pp. 141-162.

[9] Baran, B. (2010) "Facebook as a Formal Instructional Environment", British Journal of Educational technolog, 41 (6), pp. 146-149.

[10] Churchill, D. (2009) "Educational Applications of Web 2.0: Using Blogs to Support Teaching and Learning", British Journal of Educational Technology 40 (1), pp. 179183.

[11] Roblyer, M. D. (2010) "Findings on Facebook in Higher Education: A Comparison of College Faculty and Student Uses and Perceptions of Social Networking Sites", Internet and Higher Education 13 (3), pp. 134-140.

[12] Keenan, A., \& Shirri, A. (2009) "Sociability and Social Interaction on Social Networking Websites", Library Views 58 (6), pp. 438-50.

[13] Mazer, Murphy, R. P., \& Simmonds, C. J. (2007) 'I'll See You on Facebook: The Effects of Computer Mediated Teacher Self-Disclosure on Student Motivation, Affective Learning and Classroom Climate", Communication Education 56, pp. 1-17.

[14] Haq, A., \& Chand, S. (2012) "Pattern of Facebook Usage and its Impact on Academic Performance of University Students: A Gender based Comparison", Bulletin of Education and Research 34 (2), pp. 19-28.

[15] Pempek, T. A., Yermolayeva, Y. A., \& Calvert, S. L. (2009) "College Students Social Networking Experiences on Facebook", Journal of Applied Developmental Psychology 30 (3), pp. 227-238.

[16] Kirschner, P. A., \& Karpinski, A. C. (2010) "Facebook and Academic Performance", Computers in Human Behaviour 26, pp. 1237-1245.

[17] Junco, R. (2012) "Too Much Face and not Enough Books: The Relationship between Multiple Indices of Facebook Use and Academic Performance", Computers in Human Behaviour 28 (6), pp. 187-198.

[18] Ahmed, I., \& Qazi, T. F. (2011) “A Look Out for Academic Impacts of Social Networking Sites: A Student Based Perspective", African Journal of Business Management 5 (12), pp. 5022- 5031.

[19] Lennon, R., Rentfro, R. W., \& Curran, J. M. (2012) "Exploring Relationships between Demographic Variables and Social Networking Use", Journal of Management and Marketing Research 11, pp. 1.

[20] D' Agostino, S. (2010). "Facebook and Texting Vs. Textbook and Faces", Math Horizons 18 (1).
Abbreviations Used in Table $2 \& 3$

\begin{tabular}{|l|l|}
\hline SA & Strongly Agree \\
\hline A & Agree \\
\hline UN & Undecided \\
\hline DA & Disagree \\
\hline SDA & Strongly Disagree \\
\hline
\end{tabular}

Abbreviations Used in Figure 2

\begin{tabular}{|l|l|}
\hline Downloading music/video & DM \\
\hline Uploading music/video & UM \\
\hline Posting photos & PP \\
\hline Blogging & BG \\
\hline $\begin{array}{l}\text { Communication with } \\
\text { teachers/class fellows }\end{array}$ & CMC \\
\hline Chatting & $\mathrm{CH}$ \\
\hline Submitting assignments & SA \\
\hline Any other & OTH \\
\hline
\end{tabular}

